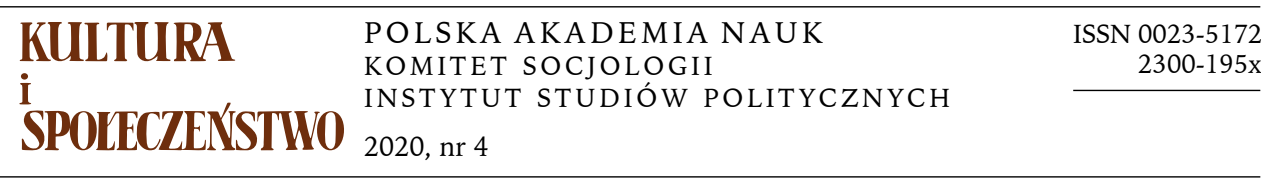
$\begin{array}{lllllllll}A & R & T & Y & K & U & £ & Y\end{array}$
I
$\begin{array}{llllllll}\mathrm{R} & \mathrm{O} & \mathrm{Z} & \mathrm{P} & \mathrm{R} & \mathrm{A} & \mathrm{W} & \mathrm{Y}\end{array}$

JULITA CZERNECKA

Uniwersytet Łódzki

\title{
ZNAKI MIŁOŚCI — PRAKTYKI TWORZENIA ZWIĄZKU INTYMNEGO*
}

\begin{abstract}
WSTĘP
Problematyka dotycząca związków miłosnych od wielu dekad stanowi przedmiot refleksji nauk społecznych. W centrum zainteresowań stawiane są zagadnienia ich przebiegu „od zakochania do rozstania”, czyli między innymi społeczne uwarunkowania doboru partnerskiego (Blackwell, Litchter 2000; Beck, Beck-Gernsheim 2013; Przybył 2017; Kalinowska 2018), powstanie i dynamika związków miłosnych (Blood, Wolfie 1960; Kwak 2005; Bauman 2005; Jamieson 2008; Giddens 2006; Szukalski 2013; Schmidt 2015; Żadkowska 2016; Stasińska 2018), przyczyny ich rozpadu (Illouz 2016; Paprzycka, Mianowska 2019). Istotnym polem eksploracji naukowych stało się także badanie intymności w relacjach dwojga osób (Bieńko 2013). Poniższe rozważania wpisują się właśnie w nurt refleksji dotyczącej życia intymnego pary i praktykowania życia we dwoje (Schmidt i in. 2018), a także w obszar badań nad semiotyką miłości, czyli podejścia, które ma na celu zrozumienie miłości poprzez znaki, symbole i inne struk-

Adres do korespondencji: julita.czernecka@uni.lodz.pl; ORCID: 0000-0001-8592-8980

* Analizowany poniżej materiał empiryczny pochodzi z projektu badawczego „Społeczne definiowanie miłości i roli, jaką odgrywa ona w trwaniu heteroseksualnego związku intymnego", zrealizowanego w 2018 roku na Uniwersytecie Łódzkim w ramach zdań statutowych.
\end{abstract}


tury będące nośnikami znaczeń, których ludzie używają do jej wyrażania (Danesi 2019).

Brana tu pod uwagę idea miłości zakłada wolną wolę w wybieraniu partnera i konstytuuje autonomię podmiotów połączonych więzią miłości (Illouz 2016, s. 21-22). Proces indywidualizacji czyni jednostkę odpowiedzialną za swoje życie, a tym samym za jakość związku miłosnego i to, czy zakończy się on w subiektywnym przekonaniu sukcesem czy porażką. Satysfakcja życiowa - także w obszarze miłości - staje się „zadaniem do wykonania”, a „obowiązkiem” człowieka jest ulepszanie swoich relacji $z$ innymi, przekraczanie własnych ograniczeń, a także pokonywanie wszelkiego rodzaju przeszkód, które uniemożliwiają samospełnienie, również w relacjach intymnych (Bauman 2005, s. 5-40). Relacja oparta na równych prawach partnerów, którzy łączą się ze sobą z powodu miłości i tylko miłości, „W imię indywidualistycznie pojętych celów natury uczuciowej”, nie służy zatem żadnym zewnętrznym celom, jest inicjowana i kończona zgodnie z wolą partnerów (Illouz 2016, s. 23). Dotyczy tego koncepcja Anthony'ego Giddensa (2006, s. 75) „czystej relacji”, która polega na tym, że „jednostki wchodzą w związek dla niego samego, czyli dla tego, co każda $z$ nich może wynieść $z$ trwałej więzi z drugą osobą, i trwa tylko dotąd, dokąd obie strony czerpią z niej dość satysfakcji, by chcieć ją utrzymywać" — kiedy emocje się „wypalają” para „powinna” się rozstać.

Współczesne rozumienie miłości w dużej mierze odnosi się do obrazu miłości romantycznej, a jednocześnie trwałej, która bazuje na bliskiej więzi między dwojgiem ludzi. Nadaje ona sens życiu, ponieważ „druga osoba staje się całym światem" (Beck, Beck-Gernsheim 2013). Zakłada autorefleksję dotyczącą tego, co partnerzy wzajemnie do siebie czują i czy te uczucia są wystarczająco głębokie, żeby budować i utrzymywać stabilny związek. Miłość stała się zatem podstawą tworzenia dalekosiężnych planów życiowych, pozwalającą tworzyć „wspólną historię” opartą na więzi emocjonalnej i porozumieniu duchowym. Jednocześnie zaczęło jej towarzyszyć cierpienie będące wyrazem i przejawem dylematów oraz bezradności nowoczesnej podmiotowości. „Doświadczenia porzucenia i braku wzajemności stanowią kluczowy element życiowej narracji" (Illouz 2016, s. 30).

W kulturowym wzorcu miłości, szczególnie tej romantycznej, tkwią przeobrażenia rozumienia związku intymnego, ponieważ jego podstawą staje się więź, która utrzymuje się wówczas, kiedy są spełnione określone warunki (zob. Beck, Beck-Gernsheim 2013). Można powiedzieć, że współczesne pary tkwią $\mathrm{w}$ pułapce polegającej na niekończącym się analizowaniu, czy obecny związek im odpowiada, czy nie, czy chcą pozostać razem, czy się rozstać. Życie osobiste stało się niczym nigdy niekończący 
się „projekt” do zrealizowania, który generuje ciągłe wyzwania i produkuje lęki oraz obawy. Zarówno sukcesy, jak i porażki w miłosnej biografii jednostki przypisują na ogół samym sobie, zwykle nie dostrzegając kontekstu głęboko zakorzenionych uwarunkowań kulturowych (być może ze względu na dominację dyskursu psychologicznego w przekazach kulturowych) (Giddens 2006; Beck 2004). Rodzaj nadziei związanej z poczuciem przewidywalności i stabilności egzystencji daje zintegrowany zespół praktyk, które człowiek podejmuje nie tylko dlatego, że są użyteczne, ale także dlatego, że nadają materialny kształt odpowiedziom na pytania dotyczące własnego życia, w tym życia intymnego, miłosnego (Giddens 2006; Illouz 2016). Eva Illouz w tym kontekście pisze o reżimie performatywności emocji i reżimie autentyczności uczuć. Pierwszy polega na tym, że emocje wzbudzane są przez zrytualizowane działania oraz wyrażenie określonych uczuć - czyli w pewnym sensie to emocje jednego partnera wzbudzaja emocje $\mathrm{w}$ drugim. W reżimie emocji ulegającym zrytualizowaniu ujawnia się własne uczucia i doświadcza określonych emocji, jeśli partner właściwie zdekoduje ich znaczenie. „Jest to więc proces dokonujący się stopniowo, częstokroć zapoczątkowany przez posłużenie się stosownymi znakami i kodami miłości. Stanowi on rezultat subtelnej zmiany znaków i sygnałów pomiędzy dwojgiem ludzi” (Illouz 2016, s. 51). Reżim autentyczności uczuć z kolei każe ludziom wnikać w ich własne uczucia i uczucia drugiej osoby, analizować je i poddawać refleksji. Osoby, które łączy relacja miłosna, znając swoje uczucia, podejmują odpowiednie działania, które stają się spoiwem relacji (Illouz 2016, s. 53).

Mężczyźni i kobiety, stojąc wobec własnych wyborów, muszą odpowiadać na pytania, co sami wniosą do relacji, w jaki sposób chcą tworzyć - ich zdaniem - udane relacje intymne. Stają się mimowolnymi obserwatorami życia intymnego innych par - przyjaciół, znajomych, członków rodziny, a także odbiorcami wielu przekazów kulturowych, w które w ostatnich dekadach obfitują — również w Polsce — chociażby popularne programy telewizyjne. W programach tych ludzie się poznają w celach stworzenia relacji miłosnej, erotycznej, a także w celu matrymonialnym (np. „Rolnik szuka żony”, „Ślub od pierwszego wejrzenia”, „Wyspa miłości”, „Sanatorium miłości”). Na oczach widzów analizowane są różnego rodzaju problemy w związkach (np. „Terapia dla par”). Poszukiwanie miłości i budowanie trwałych relacji intymnych to tematy wielu poradników dla par, singli, rozwodników. Służy temu również cała sfera popkulturowa - filmy i seriale o miłości, książki, powieści i piosenki na ten temat. Jednostki uwikłane w różne uwarunkowania kulturowe i doświadczenia indywidualne próbują zatem uchwycić logikę funkcjonowania w miłosnym 
związku i podejmują próbę jej wdrażania w swoich codziennych praktykach dotyczących własnych relacji i czynienia ich udanymi oraz trwałymi. Zaangażowanie $\mathrm{w}$ związek polega współcześnie na dokonaniu wyboru, porzuceniu dalszego poszukiwania „alternatywnych” partnerów, bo obecny wydaje się najlepszą z możliwych „opcji” — lub chociaż „wystarczająco dobrą". Jest to porzucenie dalszej optymalizacji swojego miłosnego życia (Illouz 2016, s. 156).

Warto podkreślić, że ten „uczuciowy zamęt” funkcjonuje w reżimie autentyczności, „prawdziwego Ja”, w którym decyzje jednostek muszą odzwierciedlać ich uczucia. „Czyste relacje” z jednej strony dały możliwość wolności wyboru, $z$ drugiej jednak osłabiły emocjonalną stabilność sfery prywatnej, a romantyczna świadomość stała się świadomością narażoną na cierpienie związane $z$ brakiem pewności co do trwałości związku. Dlatego interesującym może być przyjrzenie się codziennym praktykom osób żyjących w parach, skierowanym na „podtrzymanie” związku intymnego, miłosnego i czyniącym go - w ich opinii - trwałym, szczęśliwym i udanym. Praktyki te przepełnione są określoną symboliką i znaczeniami silnie zakorzenionymi w naszej kulturze.

\section{KONTEKST TEORETYCZNY, PROBLEMATYKA I METODOLOGIA BADAŃ}

Miłość jest uniwersalną emocją doświadczaną przez większość ludzi we wszystkich epokach historycznych i w różnych kulturach świata, ale przejawiającą się na różne sposoby, ponieważ kultura ma istotny wpływ na wyobrażenia o miłości oraz na to, w jaki sposób ludzie czują, myślą i zachowują się w romantycznych związkach (Karandashev 2015). Teoretycznym punktem wyjścia tych rozważań stały się, po pierwsze, przedstawione na wstępie koncepcje, w których miłość jest kluczowym spoiwem intymnych relacji międzyludzkich (m.in. Giddens 2006; Beck, Beck-Gernsheim 2013; Illouz 2016;). Po drugie, miłość można rozpatrywać jako zbiór codziennych praktyk nakierowanych na wytwarzanie i utrzymywanie bliskiej relacji (Kauffman 2007, 2012). Kolejną inspiracją teoretyczną jest semiotyka miłości, w myśl której przyjmuje się, że miłość możemy rozumieć poprzez określone znaki i symbole oraz inne struktury znaczeń przypisanych jej na przestrzeni czasu w określonej kulturze. To założenie dotyczy tego, w jaki sposób przekształcamy nasze uczucia w słowa, gesty, symbole i konstrukcje oparte na znakach, jak rytuały, które następnie pozwalają nam je poddać refleksji (Danesi 2019). Ludzie mogą wyrażać swoją miłość wobec partnera w sposób bezpośredni za pomocą słów, miłego tonu głosu, uśmiechu, specjalnymi gestami, takimi jak przytulenie. Mogą także 
robić coś dobrego dla partnera, wtedy staje się to ukrytym i pośrednim sposobem wyrażania miłości (Danesi 2019).

W jaki sposób na co dzień ludzie okazują sobie miłość i za pomocą jakich gestów lub symboli to czynią? Warto podjąć próbę odpowiedzi na to pytanie, łącząc wskazane trzy perspektywy patrzenia na związki miłosne. Warto także przyjrzeć się ich kulturowym znaczeniom, ponieważ - jak się okazuje - niejednokrotnie banalne gesty mają głęboko zakorzeniony sens i znaczenie w naszej kulturze.

Miłość opisywana jest przez socjologów w różnych kontekstach. Niklas Luhmann (2003) rozumie ją jako specyficzny język komunikacji, który koduje intymność. Norbert Elias (2011) definiuje miłość jako cywilizacyjnie zmienną formę bliskich związków. Anthony Giddens (2006) i Zygmunt Bauman (2005) w miłości widzą główne spoiwo współczesnych relacji. Podobnie Jean-Claude Kaufmann (2007) traktuje ją jako zbiór codziennych praktyk, które wytwarzają i podtrzymują intymność między jednostkami. Eva Illouz $(1997,2010)$ pojmuje miłość jako utowarowioną romantyczną utopię, podlegającą prawom rynku. Antropolożka Helen Fisher (2012, 2016) miłość rozpatruje jako zespół mechanizmów fizjologicznych wywołujących erotyczne napięcie między ludźmi. Jest ona także rozumiana jako rodzaj ucieleśnionej intencjonalności przyciągającej osoby do siebie.

Socjologia, choć podejmuje próby „odczarowania miłości”, analizując ją jako zjawisko, dyskurs o niej, to, co ją determinuje i zmienia, nie tworzy jednak stricte definicji miłości. Brak jednoznacznej, jasnej definicji powoduje, że trudno to pojęcie zoperacjonalizować, a zjawisko poddać analizie i refleksji. Takie wyzwanie podjął Krzysztof Konecki (2003, s. 10): „Miłość - jak pisze - [...] jest trwałym i niezwykle intensywnym działaniem, które [...] to może mieć charakter stricte interakcyjny, wyobrażeniowo interakcyjny, bądź odnosić się myślowo i relacyjnie do obiektu zewnętrznego wobec podmiotu, z którym chce się zjednoczyć". Ludzie deklarujący, że łączy ich miłość, często wspólnie mieszkają, funkcjonują w jednej czasoprzestrzeni, mają bezpośredni dostęp do uczuć i intencji partnera/partnerki. Interpretują pewne gesty, zachowania, słowa, inne działania jako „znaczące”, wykonywane „dla” lub „na rzecz” partnera i w celu „podtrzymania związku".

Ponieważ socjologia nie dysponuje definicją miłości, która stałaby się użyteczna w zaplanowanej analizie, inspiracją stała się trójczynnikowa koncepcja miłości Roberta Sternberga (1986), psychologa, który odwołuje się do jej trzech wymiarów: intymności, namiętności i zaangażowania. Intymność to wszelkie pozytywne uczucia, takie jak przeżywanie szczęścia W obecności partnera, a także $z$ jego powodu, pragnienie jego dobra, wza- 
jemne zrozumienie, dzielenie się przeżyciami, otrzymywanie wparcia emocjonalnego, wymiana informacji o charakterze intymnym, budowanie bliskości. Intymność jest w dużej mierze wynikiem komunikacji między partnerami i rozumienia wzajemnie swoich potrzeb. Umiejętne rozpoznawanie potrzeb partnera przychodzi z czasem, bazuje na komunikacji niewerbalnej, na podstawie wyrazu twarzy, gestów przekazywane są myśli i uczucia. Drugim składnikiem miłości jest namiętność związana z przeżywaniem pożądania, podniecenia seksualnego - stanom tym towarzyszy chęć bycia w bliskim kontakcie fizycznym, erotycznym $z$ drugą osobą. Przejawami namiętności są pocałunki, pieszczoty, kontakty seksualne. Trzecim wymiarem jest zaangażowanie $\mathrm{w}$ utrzymanie związku, czyli podejmowanie różnych działań mających na celu istnienie związku i czynienie go satysfakcjonującym. Składają się na to decyzje i działania o różnym charakterze, które są ukierunkowane na to, by uczynić związek trwałym (Sternberg 1986).

W pierwszej kolejności zebrany materiał badawczy został przeanalizowany z wykorzystaniem kategorii analitycznych zaczerpniętych z koncepcji Roberta Sternberga, tak by je przyporządkować aspektom identyfikowanym jako obszar intymności, namiętności i zaangażowania. Dzięki temu możliwe było wstępne uporządkowanie zgromadzonego materiału i jego pogłębiona jakościowa eksploracja, już w nawiązaniu do praktyk społecznych, oraz dokonanie interpretacji symbolicznej nawiązującej do analiz semiotycznych Marcela Danesi (2019).

„Praktyki miłosne” wpisują się w obszar analiz socjologii codzienności, który — zdaniem Piotra Sztompki (2008) — staje się odpowiedzią na przyspieszone zmiany społeczne, wywołujące w jednostkach „zagubienie, pewną dezorientację i traumę zmienności" i kierujące ich zainteresowania w stronę codziennej egzystencji i jej problemów. Sposób myślenia o własnym życiu w dużej mierze jest kalką uwarunkowań makrospołecznych (nie zawsze dostrzeganą przez jednostkę), a także uwarunkowań mezzoi mikrospołecznych. Z pewnością coraz więcej ludzi poddaje refleksji swoje rutynowe działania (miało to miejsce także podczas procesu badawczego). „W badaniach socjologii codzienności mieści się ogromny obszar tematów, w których poszukuje się zrozumienia świata społecznego jako struktury, której podstawową właściwością są sensy i znaczenia tworzone przez ludzi w ich codziennej aktywności. Jest to próba dokumentowania form intymnej działalności symbolicznej, potwierdzanie prawd niejako oczywistych, uznanie udziału wiedzy potocznej i kompetencji praktycznej w stałym wytwarzaniu relacji społecznych. Jednostkowe, codzienne, «naturalne doświadczanie» świata charakteryzuje się jego niekwestionowalnością" (Bieńko 2013, s. 22). 
Przedstawiana tu analiza sięga do teorii praktyk społecznych, która dostarcza interesującej - jak się wydaje - propozycji prowadzenia badań dotyczących bliskich związków. Związek intymny jest budowany na bazie codziennych działań podejmowanych przez osoby w nim pozostające, a analiza koncentruje się właśnie na tych praktykach, które czasem mogą być postrzegane jako banalne i trywialne, ale dzięki swojej powtarzalności „wytwarzają” parę. Praktyki to „otwarte, przestrzennie i czasowo rozproszone wiązki/zespoły/układy [nexus] tego, co się robi i mówi" (Schatzki 2012, s. 14; cyt. za: Sikorska 2018, s. 37).

Definicja Theodore'a Schatzkiego sugeruje, że praktyki są rodzajem strumienia aktywności ludzkiej, tego, co się mówi i robi. Praktyki są zmienne i nie zawsze redukowane do działań rutynowych, charakterystyczne dla określonego czasu i miejsca, dotyczą sfery werbalnej (tego, co jest mówione) i cielesnej (tego, co jest robione), a poza tym praktyki mają charakter całościowy - odnoszą się do pewnych układów działań, które są powiązane przyczynowo i są celowe (Sikorska 2018). Praktyki odnoszą się także do „wiedzy, jak coś się robi” - czyli jak pisze Małgorzata Sikorska (2018, s. 38) - do „wiedzy-przepisu”, która jest stosowana przez jednostkę $\mathrm{w}$ jej działaniach. W tym przypadku analizowane wypowiedzi uczestników badania odnosiły do tego, w jaki sposób - w ich opinii i refleksji, samoświadomości - buduje się udany i trwały związek w codziennych praktykach.

Przedstawiona dalej analiza wpisuje się w koncepcję socjologii pary, której autorzy (Schmidt i in. 2018) zachęcają do przyglądania się codziennym praktykom osób funkcjonujących w związku. W tym ujęciu relacje intymne są różnymi formami praktykowania miłości i bliskości. Para intymna to związek dwóch osób, które same siebie uważają za parę oraz którze są przez innych tak postrzegane (Schmidt i in. 2018, s. 14). Para może być parą małżeńską, ale nie musi, nie musi także mieszkać razem. Najistotniejsze jest to, że dane osoby „są ze sobą w związku” — ważne jest skupienie się na relacyjności. Para w tym ujęciu jest także traktowana jako dynamicznie rozwijający się układ społeczny, który przechodzi przez różne formy życia „razem”, w którym kształtuje się własny system komunikacji, a intymność staje się sposobem doświadczania świata. To „zestaw elastycznych, zmiennych w czasie praktyk relacyjnych" (Schmidt i in. 2018, s. 21). Dwoje ludzi określa zatem, w jaki sposób będzie swoją relację praktykowało, często odnosząc się do kulturowych scenariuszy, innym razem tworząc własne „znaki” miłości. Nietrwałość i kruchość współczesnego „bycia we dwoje" powoduje, że jednostki starają się podejmować różnego rodzaju działania na rzecz utrzymania satysfakcjonującej relacji z partnerem/part- 
nerką. „Takie ujęcie pary jako procesu każe badać jej życie codzienne i dążenie do zakorzenienia go w przyzwyczajeniach, artefaktach oraz rytuałach [...]. Pary i rodziny [...] tworzą się $\mathrm{w}$ działaniu, poprzez najróżniejsze praktyki codzienności, w tym zwłaszcza opiekę, troskę, pracę relacyjną [...], obowiązki domowe i ich podział. Para jest więc materializacją praktyk i jest procesem, ciągłym dokonaniem, czymś wymagającym nieustannego podtrzymywania lub przywracania" (Schmidt i in. 2018, s. 28)

Podczas realizacji badania „Społeczne definiowanie miłości i roli, jaką odgrywa ona $\mathrm{w}$ trwaniu heteroseksualnego związku intymnego" przeprowadzono osiem zogniskowanych wywiadów grupowych (FGI - Focus Group Interview), osobno z kobietami i mężczyznami, w przedziałach wiekowych ustalonych według cyklu życia (Dobrowolska 1992), czyli 19-25 lat, 26-37 lat, 38-55 lat oraz powyżej 55 lat. Wszyscy uczestnicy badania mieli co najmniej dwuletnie doświadczenie w związku intymnym, miłosnym. W większości były to wieloletnie, stałe związki partnerskie lub małżeńskie (staż związku był proporcjonalny do wieku uczestników oraz uczestniczek badania i trwał od 2 do 40 lat). Badani mieli wykształcenie wyższe lub średnie. Spotkania grup fokusowych miały charakter eksploracyjny, celem było zaprojektowanie przyszłych szerszych badań. W sesjach uczestniczyło od 5 do 7 osób, co pozwoliło na stworzenie bardziej kameralnej sytuacji badawczej, niezbędnej ze względu na intymny charakter poruszanej tematyki. W mniejszych grupach można dogłębniej i bardziej szczegółowo rozpatrywać poszczególne wątki, dopytując uczestników i pogłębiając ich wypowiedzi. „To sprawia, że ten sposób badania przypomina wywiady indywidualne, ale zachowuje interakcje pomiędzy badanymi" (Lisek-Michalska 2013, s. 18). Mniejsze grupy lepiej się sprawdzają, kiedy poruszany temat wymaga dużego zaangażowania uczestników, którzy mają do niego emocjonalny stosunek, a omawiane zagadnienie jest wieloaspektowe. Dzięki temu pojawia się możliwość artykułowania częstszych i dłuższych wypowiedzi (Lisek-Michalska 2013). I tak stało się w omawianych badaniach, podczas których uczestnikcy/uczestniczki w większości bardzo otwarcie i swobodnie dzielili się własnymi doświadczeniami w obszarze funkcjonowania w związkach, niejednokrotnie poruszając bardzo intymne aspekty.

Eksploracyjny charakter badań oraz ograniczenia użytych narzędzi nie pozwalają na zweryfikowanie deklaratywnej wiedzy ani obiegowych opinii, które często są prezentowane w tego typu badaniach. W konsekwencji uzyskane wyniki są uproszczone (zwłaszcza jeżeli opieramy się na wypowiedzi tylko jednego partnera związku). Poniższa analiza nie odnosi się stricte do interakcji, ponieważ badanie nie opiera się na obserwacjach 
i zachowaniach pary w relacjach ze sobą, lecz śledzi te interakcje na podstawie wypowiedzi uczestników badania — inaczej mówiąc jest to jedyne „bierne” odtwarzanie interakcji, o których mowa. Uzyskany materiał nie pozwala ani na analizę głębszego wymiaru doświadczenia bycia w związ$\mathrm{ku}$, ani na generalizację wniosków (np. dotyczących różnic klasowych). Jakościowy sposób analizy nie daje pełnego obrazu przedmiotu badania, jednak w pewnym stopniu pozwala na rozpoznanie obszaru praktyk codzienności i stanowi bazę do projektowania dalszych pogłębionych badań. Potrzebnych zwłaszcza dlatego, że większość studiów dotyczących tej tematyki to badania psychologiczne lub etnograficzne, które skupiają się na tym, w jaki sposób ludzie myślą o miłości lub jej doświadczają (Sprecher, Metts 1999; Brantley, Knox, Zusman 2002; Fehr 2006; Schmitt i in. 2009).

\section{OD PRAKTYK BUDOWANIA INTYMNOŚCI I NAMIĘTNOŚCI DO GESTÓW ROMANTYCZNYCH}

\section{Intymne gesty miłości}

„Intymność jest pewnym stanem uczuć, myśli, nastawień, gestów, który wytwarza się w sprzyjających warunkach między osobami ufającymi sobie do tego stopnia, że na czas kontaktu zdejmują zwykle stosowane w życiu społecznym zapory i zabezpieczenia, działają i wypowiadają się otwarcie, nie stosując manipulacji” (Bieńko 2013, s. 28). Codzienne praktyki budowania intymności w tym kontekście dotyczą bliskości fizycznejw nieerotycznym kontekście. Dotykanie, przytulanie, pocałunki dla wielu uczestników badań stawały się świadectwem miłości. Pocałunki („na powitanie”, „na dzień dobry”, „na pożegnanie”, „na dobranoc”, „na znak miłości bez okazji") czy przytulanie (podczas snu, wspólnej popołudniowej drzemki, przy okazji wykonywania codziennych czynności) stawały się oczywistymi, łatwo odczytywanymi znakami miłości.

Takie małe gesty - na przywitanie buziak, albo przytulenie się, podejście i dotykanie tej drugiej, trzymanie się za rękę. [...] Lubię jak na przykład siedzi przy komputerze podejść, objąc go, dać mu buziaka, wiem, że jest zajęty, coś tam robi, tylko na chwilkę podejde, staram się mu nie przeszkadzać, ale takie mamy drobne gesty [FGI/K19-25/2] ${ }^{1}$.

To ta bliskość, która jest przez caty czas, przez caty dzień. Gdzie rano się budzisz, witasz się pocałunkiem, wychodzisz i żegnasz się pocałunkiem znowu kiedy każ-

1 Oznaczenia: FGI - Focus Group Interview - wywiad fokusowy; K — kobieta, M mężczyzna; 19-25, 26-37, 38-55, 55+ - grupy wiekowe; 2 - numer respondenta/ki. 
dy idzie do pracy, w ciagu dnia do siebie dzwonimy, pytam co robisz, gdzie jesteś [FGI/K26-37/6].

Codziennie jak razem śpimy to śpimy przytuleni i od tych ośmiu lat to nie zdarza się raczej inaczej, więc dla mnie to jest jeden $z$ takich ważniejszych potwierdzeń naszej mitości [FGI/K26-37/2].

Bliskość to jest, gdy witamy się pocatunkiem, przytulimy się powiemy co tam stychać, poklepiemy się po plecach [FGI/M26-37/2].

Fizyczny kontakt jest niezwykle ważny. Dotyk jest jednym z najpierwotniejszych, a zarazem najważniejszych sposobów nawiązywania, budowania i podtrzymywania kontaktów społecznych (Leathers 2007, s. 139-150). „Dotykanie i bliska odległość sygnalizują pragnienie bliskości i bezpośredniości, chociaż fizyczny akt dotykania może wymagać większej fizycznej bliskości niż ta, która jest odpowiednia w miejscu publicznym" (Leather 2007, s. 148-149). Bliskość przestrzenna także komunikuje nam określone znaczenia, zwłaszcza ta dotycząca sfery intymnej (Hall 1976). „Dotyk pełni ważne funkcje komunikacyjne, mianowicie może to być funkcja wspierająca, która wiąże się z tym, że dotyk jest efektywnym środkiem komunikacji emocjonalnej. [...] Może także komunikować o "przynależności», czyli o tym, że na przykład dwie osoby bardzo się lubią" (Konecki 2008, s. 79-80) i/lub kochają.

Rozmówcy szczególnie zwracają uwagę na pocałunki, które mogą być pocałunkami w usta, w policzek, w czoło, dłoń... Dotknięcie innego człowieka ustami - jak pisze Otto Best (2003) - ma przeróżne znaczenia historyczno-kulturowe, ale od czasów starożytnych często było utożsamiane właśnie ze „znakiem miłości”. Z kolei gest dotykania ręką twarzy partnera, obejmowania się, trzymania się za rękę pojawia się u zarania świadomości ludzkiej. Być może stało się tak na skutek ewolucji, w toku której „dwunożność” uwolniła ludzką rękę, pozwalając jej stać się niezwykle „czułą kończyną" służącą także do przekazywania uczuć innym poprzez gestykulację i dotyk. Nie jest zatem wykluczone, że czułość mogła być jednym z pierwszych stanów emocjonalnych doświadczanych przez ludzi. Przytulanie się jako oznaka wsparcia, współdzielenia bliskości, przekazywania szczęścia są powszechnymi, wzajemnie powiązanymi znakami (Danesi 2019). Dotyk staje się wyrazem uczucia troski i dbania o drugą osobę. Dla uczestników tych badań był szczególnie istotny jako „znak pojednania” - po sprzeczkach, nieporozumieniach czy konfliktach, które kończą się przytuleniem, uściskiem, objęciem:

Kiedy mamy jakiś konflikt pokłócimy się i naprawiliśmy, to on się potrzebuje do mnie przytulić, on potrzebuje tak żeby byto sto procent dobrze [FGI/K26-37/3]. 
Badani mówili również o prowadzeniu rozmów w fizycznej bliskości, na przykład w łóżku (które często jest wskazywane jako najbardziej intymna przestrzeń w domu), siedząc blisko na kanapie czy na kolanach partnera (na przykład przy wspólnym oglądaniu filmów).

Intymność opiera się także na uzyskiwaniu wsparcia emocjonalnego. Przez „wsparcie” rozumie się pomoc, rodzaj interakcji społecznej, jednostronnej lub dwustronnej, podczas której dochodzi do przekazania lub wymiany emocji lub innych instrumentów działania (Sęk, Cieślak 2006). W relacji intymnej, miłosnej, związek między partnerami ma charakter stały - to, co zmienne, zależy od tego, kto $\mathrm{w}$ danym momencie jest w większym stopniu „dawcą” wsparcia, a kto jego „biorcą”. Z wypowiedzi badanych wynika, że zależy to od konkretnej sytuacji, w jakiej uczestnicy badania lub ich partnerzy się znaleźli. Uczestnicy badania najczęściej odwoływali się do wsparcia emocjonalnego jako podstawy udanego związku i miłości - o czym pisali Ulrich Beck i Elisabeth Beck-Gernsheim (2013), nazywając związek „wspólnotą emocjonalną”. Ta emocjonalna bliskość zdaniem uczestników badania - świadczy o zaangażowaniu w relację, o tym, że partnerom zależy na związku.

Jak mam zły dzień i on mówi chodźmy na obiad, zapomnisz, nie martw się, motywacja taka. To jest dla mnie troska, że on pozwala mi uspokoićsięjakjestem zdenerwowana, jak jestem załamana to zmotywuje mnie zawsze, i to jest dla mnie ta troska, która jest najważniejsza tak naprawdę [FGI/K19-25/2].

Kiedy cię widzi, czy chora, czy zdrowa [...] i to jest ta bliskość, że nie jest ważne jak wygladamy, jak się czujemy, czy mamy włosy czyste, czy przettuszczone, czy mamy gorączkę $i$ jesteśmy spocone, $w$ bieliźnie $i$ chodzimy tak po domu, czy robimy cokolwiek, zawsze jesteś wyjątkowy dla drugiej osoby [FGI/K19-25/1].

Problemy, obowiązki, codzienne życie. Kiedy jesteśmy razem, to jest wtaśnie taki moment dostownie zapomnienia, dla mnie to stowo dosłownie odwzorowuje [miłość] [FGI/K19-25/5].

To rozumienie bez stów, że ktoś już się domyśla, co ta druga osoba może myśleć. Nie trzeba sięo wszystko pytać [FGI/M26-37/4].

Opisywane praktyki „intymne” stały się doświadczaniem takiego rodzaju, jaki w innych obszarach życia codziennego nie jest spotykany — to całkowite skupienie uwagi i działań na partnerze. W takich interakcjach dostrzegamy zawieszenie kryteriów oceny drugiej osoby, zawieszenie to dotyczy także kodów komunikacji oraz wzorów zachowań cielesnych. Dla uczestników badania istotne było uzyskanie akceptacji tego, że „mogą być sobą”, nie udając kogoś innego, realizować „prawdziwe - ja” przy pełnej aprobacie partnera. Taka akceptacja wyraża się za pomocą słów lub/i ge- 
stów zwłaszcza w sytuacjach trudnych, odmiennych, takich jak choroba czy złe samopoczucie. Istotne było także „bycie razem tu i teraz”, „zatrzymanie chwili”, „zwolnienie tempa życia przy drugiej osobie”, „związkowy mindfulness”, „uważność na drugą osobę i jej stany emocjonalne”. To po prostu siedzenie w milczeniu, czułe spojrzenia odczytywane jako okazywanie troski. Rozmówcy zwracali uwagę przede wszystkim na to, że udana relacja między dwojgiem ludzi powinna umożliwiać bliskość emocjonalną, stać się przestrzenią innego sposobu funkcjonowania niż w świecie „zewnętrznym”.

\section{Namiętne gesty miłości}

W refleksjach dotyczących funkcji współczesnych związków podkreśla się, że obok zaspokajania potrzeb emocjonalnych kluczowe znaczenie ma także zaspokajanie potrzeb seksualnych (Giddens 2006; Illouz 2016). Miłość jest powiązana fizycznie i emocjonalnie z seksem, co przejawia się w sferze erotyki. Miłość jest powiązana fizycznie i emocjonalnie z seksem, co przejawia się w sferze erotyki - bazuje ona na zmysłowości i emocjach. Marcel Danesi (2019) pisze - wydobyliśmy ją z ciała i podnieśliśmy do poziomu świadomości poprzez konkretne rodzaje przedstawień, które stoją w opozycji do tych "czysto" seksualnych, zawierających symbole miłosne. Pokazuje to, że żyjemy nie tylko w biosferze, ale także w semiosferze, wśród znaków, które umożliwiają nam myślenie o świecie w konkretnych miłosnych kategoriach. Bliskość fizyczna, zwłaszcza w wymiarze intymnym, seksualnym jest zakorzeniona $\mathrm{w}$ naszej biologicznej przeszłości, opiera się zatem na naszym wrodzonym poczuciu znaczenia emocjonalnej bliskości. W tej strefie największej bliskości uaktywniają się zmysły, a obecność drugiego człowieka jest niepowtarzalna. Dlatego najczęściej jest ona zarezerwowana dla kochanków przekazujących poczucie intymności (także innych najbliższych osób) (Hall 1976).

Praktyki podtrzymywania wzajemnej atrakcyjności erotycznej były niezwykle istotne również $\mathrm{w}$ wypowiedziach uzyskanych $\mathrm{w}$ toku badań, zwłaszcza w refleksjach dotyczących tego, że wybory miłosne nigdy nie są „do końca” wiążące i należy je „ponawiać za sprawą niekończącego się procesu wywoływania uczuć" (Illouz 2016, s. 145).

Badani przyznawali, że bliskość i intymność rodzi pełną akceptację partnera czy partnerki, zarówno co do cech osobowości, jak i wyglądu. Pewne niedoskonałości, wady czy słabości, nadając indywidualny rys „drugiej połowie”, niejednokrotnie potęgują fascynację erotyczną i pożądanie, sprawiają, że staje się w opinii partnera/partnerki niepowtarzalna i wy- 
jątkowa. Badani odnosili się w swoich wypowiedziach do działań związanych $z$ „praktykami dawania przyjemności” drugiej osobie podczas zbliżeń erotycznych, mówienia komplementów, zapewniania o swoich uczuciach, miłości. Istotna okazała się także możliwość mówienia o fantazjach seksualnych swoich i partnera/partnerki - ważne było nieodkładanie ich realizacji na „później”, na „kiedyś”. Spełnianie nawzajem swoich potrzeb umożliwia rozwój związku.

W trakcie seksu mówienie sobie o uczuciach $z$ ta druga osoba [...], że kocham cię, jesteśs wspaniała, jakieś takie stowa [FGI/K19-25/1].

[Chcę słyszeć] "tadnie wygladasz", "fajnie wygladasz" i jakby uważa, że ładnie wygladam to mówi "fajnie wygladasz" [FGI/K19-25/5].

Ja do niego podchodzę $i$ kładę mu rękę na twarz i go przytulam, a on dochodzi i mnie klepnie $w$ tyłek. Mówi mi mnóstwo komplementów, jest dość wylewny [FGI/K38-55/2].

Mówienie o jakiś swoich fantazjach seksualnych na przykład, niekoniecznie od razu o pięćdziesięciu twarzach Greya [oznacza pełną miłość] [FGI/K19-25/3].

Atrakcyjność seksualna zależy od wysoce zindywidualizowanej dynamiki gustów i psychologicznej kompatybilności partnerów, mimo że istnieją jej kulturowe prototypy (Illouz 2016). Uczestnicy zogniskowanych wywiadów grupowych poruszali także kwestię tego, „co robić”, jakie znaki dać partnerowi, żeby ten czuł się atrakcyjny, a seks w stałym związku również po wielu latach znajomości nadal był satysfakcjonujący dla obojga partnerów.

Odkrywanie mapy ciała swojego i partnerki nie ma nic wspólnego z kawalerskimi przygodami, na powiedzmy sobie krótki okres czasu, tylko to może być fascynująca podróż myśle w świat zmystów i takiego poznania się dużo głębiej samego siebie, nie tylko partnerki. To jest wtaśnie ta ekscytacja, która oczywiście [...] ona w miare uptywu czasu nieco tagodnieje, ale jest [FGI/M55+/2].

Moim zdaniem ta idea podrywania siebie nawzajem [...] zachowania tego tylko nie $w$ krótkim czasie, tylko przez pierwsze miesiące czy lata. To jest ten element jednoznaczny dla mnie osobiście obecny $w$ codziennym życiu. Ja bym powiedziat, że adorowanie, podrywanie. Niezależnie od stażu [...] to działa świetnie. Zaczęcie od pierwszej randki na nowo, zaskoczenia na mieście. To wymaga energii i motywacji [FGI/M26-37/6].

$W$ trakcie seksu mówienie sobie o uczuciach $z$ ta druga osoba jest ważne [...], że kocham cię, jesteś wspaniała, jakieś takie stowa [FGI/K19-25/1].

Kobiety przywiązywały większą wagę do wyrażania swoich uczuć słowami - „kocham cię”, „ubóstwiam cię”, ,jesteś piękna” — w trakcie lub 
po akcie seksualnym. Dla kobiet ważne były również komplementy jako potwierdzenie tego, że dla partnera pozostają atrakcyjne fizycznie, seksualnie, jako kochanki. Ta wzajemna atrakcyjność rozumiana jest dość szeroko - jako zbiór cech psychofizycznych partnerów, ale także charakter. Wzmacniana jest przez praktyki budowania „atmosfery romantyczności”. Wiele związków opiera się na wzorcu miłości romantycznej, która odnosi się do początkowej fazy znajomości, fascynacji drugą osobą, ekscytacji tym, co nieznane, odkrywane, a tym samym bardziej pociągające. Z czasem partnerzy poznają się coraz dogłębniej, w różnych obszarach codziennego funkcjonowania. $Z$ pewnością jest to rodzaj pułapki miłości romantycznej, ponieważ jednostki oczekują, że stan bycia zakochanym z początkowego etapu znajomości zostanie podtrzymany i przedłużony na „zawsze” (Beck, Beck-Gernsheim 2013). Seks jest instynktem przetrwania, ale my przekształciliśmy go $\mathrm{w}$ znaki, nadając mu znaczenie $\mathrm{w}$ określony sposób (Danesi 2019).

\section{Romantyczne gesty miłości}

Miłość romantyczna to mieszanka pożądania emocjonalnego i utrzymującej się atrakcyjności seksualnej. Analizowane wypowiedzi zwracają jednak uwagę na to, że „gesty romantyczne” pojawiają się w długoterminowych relacjach jako element, który dla jednych ma świadczyć o zaangażowaniu i niejako służyć potwierdzeniu, że partner czy partnerka „ciągle”, „nieustająco” pozostają atrakcyjni seksualnie, są przez nas pożądani. Dla innych być może są jedynie przejawem społecznie uwarunkowanego rozumienia pojęcia "kocham cię” (daje ci czekoladki, co oznacza, że chce żebyś rozumiała to, że cię kocham). Miłość romantyczna charakteryzuje się idealistycznym podejściem do związku, jest utożsamiana $z$ „miłością na zawsze", taką, która nigdy się nie kończy. W tym kontekście jej utrzymanie zależy od kultury i historycznych tradycji, które wpływają na ekspresję i doświadczenie miłości, a także na to, w jaki sposób związek dwóch kochających się osób ma być podtrzymywany (Karandashev 2015).

Gesty miłości wyrażające zaangażowanie w utrzymanie związku były rozumiane przez badanych jako działania o charakterze niecodziennym, ekskluzywnym, dającym poczucie wyjątkowości. Uczestnicy badań nazywali je „gestami romantycznymi”. Analizowane wypowiedzi pokazują, że badani niezwykle cenią te przejawy romantyzmu, bo jawnie i bezpośrednio świadczą one o zaangażowaniu w związek i dzięki nim partnerzy czują się bardziej ze sobą związani emocjonalnie, mogą „oderwać się od szarej rzeczywistości”, poczuć się szczęśliwymi i uznać, że ich relacja jest satys- 
fakcjonująca. Romantyczne znaki miłości są - w ich opinii — sposobem na zerwanie z rutyną, przyzwyczajeniem, pokazują, że mimo upływu lat nadal pojawia się chęć fizycznej i emocjonalnej bliskości z partnerem. Polegają na podejmowaniu dla niego wysiłku, ponieważ romantyzm kojarzy się z zachowaniem niespodziewanym, które ma sprawić przyjemność drugiej osobie. Uczestnicy badań dość często wskazywali kilka praktyk, które wdrażają w swoje codzienne życie, utożsamiając je z praktykami „romantycznymi".

To są dostownie jakieś drobiazgi. Kładziemy dzieci spać i nagle żona do mnie, chodźna dót, a tam świece czy sałatka, mówi: teraz mamy czas dla siebie, porozmawiajmy. I to jest też fajne taka mita niespodzianka, bo nie spodziewatem się [FGI/M38-55/6].

Dla mnie romantyczne byto to, że mój troglodyta emocjonalny, jak mi kupit prezent [pierścionek] to mi go schowat pod poduszkę. Wsunętam rękę i znalazłam. To byt przejaw romantyzmu, takiego niecodziennego, zaskakującego [FGI/K38-55/5].

Ja kupuje mojemu mężowi stodycze, on tak uwielbia słodycze. To jest już u mnie takie po tylu latach automatyczne, że jestem $w$ sklepie $i$ już pomyśle, tak, no pewnie by się ucieszyt gdybym coś przywiozła ze soba do domu [FGI/K26-37/2].

Jak idę ulica $i$ widze jakąś kwiaciarnię, to po prostu wejdę $i$ kupię te kwiaty [...] Różne. Jej będzie mito, ja się fajnie poczuje [FGI/M19-25/6].

Kwiaty oczywiście, ale bardziej podchodzę do tego, że wiem, że to sprawi komuś przyjemność [FGI/M55+/4].

Najbardziej oczywiste spośród wymienianych „znaków miłości” mają silne zakorzenienie w kulturze. Produkty spożywcze o słodkim smaku już od średniowiecza były częścią rytuałów miłosnych, także ze względu na ich niedostępność i wyjątkowość. Na przykład czekolada została przywieziona do Europy w XVI wieku i stała się luksusowym towarem wśród arystokracji — dziś jest pełna historycznych znaczeń i intencji semiotycznych, które łączą język miłości z metaforą kulturową, że miłość wiąże się ze słodyczą (Danesi 2019).

Miłość jako metafora czegoś słodkiego przejawia się także w symbolice kwiatów, zwłaszcza róży, która ma słodki zapach. Róża - zwłaszcza w kolorze czerwonym - symbolizuje miłość romantyczną od czasów miłości dworskiej. Patrząc na dawanie czekoladek i kwiatów w kategoriach semiotyki miłości, można względnie wiarygodnie uzasadnić, że te „banalne" gesty stanowią konsekwencję wcześniejszych procesów symbolicznych. Podobnie można odczytywać obdarowywanie ukochanej biżuterią, zwłaszcza pierścionkami (niekoniecznie zaręczynowymi). Od czasów starożytnych pierścionki były wymieniane jako „dowody miłości”, ponieważ 
pierścionek (tym bardziej obrączka) symbolizował, że kobieta jest „zajęta”, „jest w związku miłosnym” (dosłownie - jej ręka jest zajęta). Być może we współczesnej kulturze zachodniej zasięg tej symboliki się rozszerzył. Marcel Danesi stwierdza (2019, s. 318): „symbole i rytuały miłosne są związane $z$ naszym postrzeganiem i doświadczeniem miłości. Utrwalamy je we wspólnych praktykach i różnych ważnych dla nas wydarzeniach, aby stworzyć ogólny kodeks praktyk opartych wlaśnie na miłości”. Praktyki miłosne, takie jak podarowanie czekoladek czy róż, nabierają znaczenia tylko wówczas, gdy członkowie danej wspólnoty potrafią w odpowiedni sposób odkodować ich sens.

Praktyki podtrzymywania relacji miłosnej to także organizowanie wspólnych wyjść do kina, teatru, na koncert - dających poczucie wyjątkowości, bo są to aktywności organizowane w tajemnicy przed partnerem/partnerką, wymagają nakładów pracy i energii oraz wiążą się z nadawaniem szczególnego znaczenia takim chwilom (chociażby przez podkreślenie tego specjalnym strojem). Mamy tu do czynienia znowu z niespodzianką, tajemnicą, czymś, co ma wzbudzać emocje w partnerze/partnerce i jednocześnie staje się sposobem na utrzymanie uczucia.

Staram się zrobić taka niespodziankę, zaplanować, tutaj kupuję bilety, dzieci do babci, tutaj wyjdę wcześniej z pracy, i potem stuchaj idziemy dzisiaj do kina i mam dla ciebie niespodziankę. Ja to robię, ale mój mąż też tak robi, to jest fajne [...], nie planowanie, tylko takie zaskakiwanie się [FGI/K26-37/6].

Jakieś wyjście, wyjazd daje element świeżości, która pobudza ten zwiazek, żeby nie zakwitnać $w$ tym domu [...]. Założyć sukienkę, która tam czeka w szafie [...]. Dla mnie to jest ważne, bo ja chcę mu się podobać, chcę się dla niego wyszykować, a to jest ten moment kiedy mogę z tego korzystać [...]. Staramy się chociaż ten raz na tydzien,, raz na dwa w weekend ten dzień poświęcić dla siebie [FGI/K38-55/2].

Znaki miłości przejawiają się także w na pozór prozaicznych codziennych czynnościach. Na przykład w trakcie przygotowywania posiłków dla drugiej osoby:

Ja robię naleśniki w kształcie serduszka [FGI/K26-37/4].

Jakieś tam serduszko z keczupu zrobione na śniadaniu [...] zawsze inaczej [FGI/ M38-55/4].

To również wysyłanie sobie wiadomości „kocham cię”, przesyłanie emotikonów „serduszek” i innych treści związanych z symboliką miłości (piosenek, zdjęć, filmików), bo jak określił to jeden z mężczyzn: Telefon, sms, wszystko jest takim gestem okazania miłości [FGI/M19-25/2]. Symbol serca jest jednym $z$ emotikonów najczęściej używanych w codziennej komunikacji. Różne jego kolory zawierają odmienne znaczenia, ale najczęściej to 
właśnie czerwone serce jest symbolem miłości namiętnej, romantycznej. Kolor czerwony - tak jak w przypadku róż — jest utożsamiany z krwią, źródłem krwi jest serce i to może tłumaczyć, dlaczego jest ono uważane za symbol miłości (poprzez skojarzenia z płodnością i życiem - już starożytni Egipcjanie postrzegali serce jako organ stanowiący siedzibę uczucia miłości) (Danesi 2019). Na przestrzeni dziejów ludzie lokowali miłość w sercu, prawdopodobnie także ze względu na jego głośne, bezpieczne i pocieszające bicie (Ackerman 1991).

\section{REFLEKSJE KOŃCOWE}

Miłość nadal wymyka się próbom dotarcia do jej sedna, mimo iż współcześnie dysponujemy zaawansowanymi technologiami i technikami badawczymi. To, co uchwytne, to kulturowo uwarunkowane zachowania wpływające na ekspresję i doświadczanie miłości, przejawiające się w określonych znakach, symbolice i rytuałach. Jedni wyrażają miłość w sposób bezpośredni i jawny, inni preferują formy bardziej pośrednie i ukryte. Zatem to, czemu możemy się przyglądać okiem badacza, to codzienne aktywności i działania, które budują relacje międzyludzkie - codzienne praktyki, takie jak gesty, zwyczaje, wypowiadane słowa, sentencje, które są dla pary „znakami miłości” (Bieńko 2013). Warto zatem docierać do sensów nadawanych im przez jednostki w bieżącym „tu i teraz”, a także do ich znaczenia semiotycznego, często nieuświadomionego, które zakorzenione jest w kulturze, co ma określone uwarunkowania historyczne.

Analiza zebranego materiału badawczego to zaledwie preludium, wstęp do analiz, które w tym obszarze jeszcze można podjąć. Respondentów niejednokrotnie charakteryzuje świadomość trudu związanego $z$ budowaniem związku „do grobowej deski” - jak określał to Zygmunt Bauman (2005). Stopień refleksyjności prawdopodobnie jest związany z wykształceniem partnerów i stażem w związku. Praktyki, o których mówili uczestnicy badania, choć na ogół były rutynowo odtwarzane, to W większości stawały się przedmiotem autorefleksji i często bywały indywidualnie modyfikowane (jak w przypadku serduszek $z$ ketchupu na kanapkach ukochanej osoby).

Z pewnością moi rozmówcy w większości byli też przekonani, że ten zbiór codziennych praktyk staje się swoistą wiedzą — „przepisem”, który daje związkowi szansę „przetrwania”, „trwania w czasie”, być może nawet do końca życia, „dopóki śmierć nas nie rozłączy”. Wiele osób szuka „recepty" na stabilizację związku właśnie w odniesieniu do codziennych praktyk („robienie czegoś dla nas jako pary” lub „robienie czegoś na rzecz partne- 
ra”). Sedno dobrego życia — jak pisał Charles Taylor (2002) — przejawia się w codzienności życia, w jego „zwykłości” w odniesieniu do różnych jego obszarów - relacji rodzinnych, miłości i pracy. I wydaje się, że uczestnicy badania zdają sobie $z$ tego sprawę. Miłość zostaje uwolniona $z$ dawnych ograniczeń, ale $\mathrm{w}$ ponowoczesnym świecie „musi znosić trud stałości”, bowiem "dawniej kochankowie rozbijali się o mury instytucji, dziś brodzą w ideologii szczęścia” (Beck, Beck-Gernsheim 2013, s. 118). Obietnicą budowania trwałej relacji staje się używanie w codziennej praktyce określonych „znaków miłości” przynależnych do różnych wymiarów życia miłosnego: intymności, namiętności i zaangażowania (Sternberg 1986; por. Wojciszke 2009). Widzimy, że badani niejednokrotnie szukają recepty na „miłość kompletną”, „miłość doskonałą” chcąc łączyć wszystkie trzy aspekty w codziennych praktykach miłosnego życia pary. W przyszłości warto byłoby poszerzyć analizy, realizując badania par oraz uwzględniając aspekt płci kulturowej, co dawałoby pogłębioną możliwość przyjrzenia się omawianej problematyce. Ciekawym pomysłem byłoby poświęcenie uwagi niejawnym, pośrednim „znakom miłości”.

Ulrich Beck i Elisabeth Beck-Gernsheim (2013, s. 8) piszą: „Same jednostki, które chcą żyć razem, są — lub dokładniej — stają się coraz bardziej prawodawcami własnej formy życia [...]. Miłość, staje się pustą formułą, którą muszą wypełnić ci, którzy się kochają". Wydaje się, że jednak ta formuła nie do końca jest „pusta”, bo codzienne życie pary wypełnia szereg symboli i znaków, które - choć dla wielu są banalne, trywialne i oczywiste - nadają jednak sens byciu razem i potwierdzają jego zasadność. Czułe dotkniecie dłonią policzka partnera, przelotne muśnięcie ramienia, w końcu namiętny pocałunek, zorganizowanie niespodzianki dla „drugiej połowy”, wręczenie kwiatów czy prezentu są mocno ugruntowane w naszej świadomości jako właściwe gesty i symbole bycia razem w miłosnej relacji. Symbole i działania miłosne stają się odzwierciedleniem cielesnych impulsów, które z czasem zostają osadzone w zbiorowej percepcji jako znaczące konstrukty miłości (Danesi 2019).

\section{BIBLIOGRAFIA}

Ackerman Diane, 1991, Natural History of Sens, Vintage, New York.

Bauman Zygmunt, 2005, Razem osobno, Wydawnictwo Literackie, Kraków.

Bawin-Lergos Bernadette, 2004, Families in Europe: A Private and Political Stake - Intimacy and Solidarity, „Current Sociology”, t. 49(5), s. 49-65.

Beck Ulrich, 2004, Społeczeństwo ryzyka. W drodze do innej nowoczesności, tłum. Stanisław Cieśla, Scholar, Warszawa. 
Beck Ulrich, Beck-Gernsheim Elisabeth, 2013, Całkiem zwyczajny chaos miłości, tłum. Tomasz Dominiak, Wydawnictwo Dolnośląskiej Szkoły Wyższej, Wrocław.

Best Otto F., 2003, Historia pocałunku, tłum. Anna Kryczyńska, Muza, Warszawa.

Bieńko Mariola, 2013, Intymne i prywatne praktyki codzienności. Studium socjologiczne, Wydawnictwa Uniwersytetu Warszawskiego, Warszawa.

Blackwell Deborah, Lichter Daniel, 2000, Mate Selection among Married and Cohabiting Couples, „Journal of Family Issues”, t. 21(3), s. 275-302.

Blood Robert, Wolfie David, 1960, Husbands and Wives: The Dynamics of Family Living, Free Press Glencoe, Oxford.

Brantley Angel, Knox David, Zusman Marty, 2002, When and Why Gender Differences in Saying “I Love You” among College Students, „College Student Journal”, t. 36(4). s. 614-615.

Cieślak Roman, Sęk Helena, 2006, Wsparcie społeczne, stres i zdrowie, Wydawnictwo Naukowe PWN, Warszawa.

Danesi Marcel, 2019, The Semiotics of Love, Springer International Publishing, Springer Nature Switzerland, Kindle Edition.

Dobrowolska Danuta, 1992, Przebieg życia - fazy - wydarzenia, „Kultura i Społeczeństwo”, nr 2, s. 75-88.

Elias Norbert, 2011, O procesie cywilizacji. Analizy socjo- $i$ psychogenetyczne, tłum. Tadeusz Zabłudowski, Kamil Markiewicz, Wydawnictwo W.A.B, Warszawa.

Fehr Beverley, 2006, A Prototype Approach to Studying Love, w: Robert J. Sternberg, Karin Weis, The New Psychology of Love, Yale University Press, New Heaven.

Fisher Helen, 2012, Dlaczego on? Dlaczego ona?, tłum. Ewelina Jagła, Rebis, Poznań.

Fisher Helen, 2016, Anatomia miłości. Nowe spojrzenie, tłum. Adam Bukowski, Jacek Środa, Rebis, Poznań.

Giddens Anthony, 2006, Przemiany intymności. Seksualnossć, miłość i erotyzm we wspótczesnych spoteczeństwach, tłum. Alina Szulżycka, Wydawnicto Naukowe PWN, Warszawa.

Goffman Erving, 1977, Człowiek w teatrze życia codziennego, tłum. Helena Datner-Śpiewak, Paweł Śpiewak, Państwowy Instytut Wydawniczy, Warszawa.

Hall T. Edward, 1976, Ukryty wymiar, tłum. Teresa Hołówka, Państwowy Instytut Wydawniczy, Warszawa.

Illouz Eva, 1997, Consuming the Romantic Utopia. Love and the Cultural Contradictions of Capitalism, University of California Press, Berkeley-Los Ageles.

Illouz Eva, 2010, Uczucia $w$ dobie kapitalizmu, tłum. Zygmunt Simbierowicz, Oficyna Naukowa, Warszawa.

Illouz Eva, 2016, Dlaczego miłość rani. Studium socjologiczne, tłum. Michał Filipczuk, Wydawnictwo Krytyki Politycznej, Warszawa.

Jamieson Lynn, 2008, Od rodziny do intymności, w: Piotr Sztompka, Małgorzata Bogunia-Borowska (red.), Socjologia codzienności, Znak, Kraków.

Kalinowska Katarzyna, 2018, Praktyki flirtu i podrywu. Studium z mikrosocjologii emocji, Wydawnictwo Naukowe UMK, Toruń.

Karandashev Victor, 2015, A Cultural Perspective on Romantic Love, „Online Readings in Psychology and Culture", 5(4) (https://doi.org/10.9707/2307-0919.1135).

Kaufmann Jean-Claude, 2007, La trame conjugale. Analyse du couple par son linge, Pocket, Paris.

Kaufmann Jean-Claude, 2012, Niezwykła historia szczęśliwej miłości, tłum. Alina Kapciak, Oficyna Naukowa, Warszawa. 
Konecki Krzysztof, 2003, Odczarowanie świata dotyczy także miłości, w: Kazimierz Doktór, Krzysztof Konecki, Wielisława Warzywoda-Kruszyńska (red.), Praca - gospodarka - społeczeństwo, Wydawnictwo UŁ, Łódź.

Konecki Krzysztof, 2008, Dotyk i wymiana gestów jako element wytwarzania więzi emocjonalnej: zastosowania socjologii wizualnej i metodologii teorii ugruntowanej $w$ badaniu interakcji zwierząt i ludzi, „Przegląd Socjologii Jakościowej”, t. 4, nr 1, s. 71-115.

Kwak Anna, 2005, Matżeństwo i kohabitacja, Wydawnictwo Żak, Warszawa.

Kwak Anna, 2014, Wspótczesne związki heteroseksualne: matżeństwa (dobrowolnie bezdzietne), kohabitacje, Żak, Warszawa.

Leathers Dale G., 2007, Komunikacja niewerbalna: zasady i zastosowania, tłum. Magdalena Trzcińska, Wydawnictwo Naukowe PWN, Warszawa.

Lew-Starowicz Zbigniew, 2012, O mężczyźnie, Czerwone i Czarne, Warszawa.

Lisek-Michalska Jolanta, 2013, Badania fokusowe. Problemy metodologiczne i etyczne, Wydawnictwo UŁ, Łódź.

Luhmann Niklas, 2003, Semantyka miłości. O kodowaniu intymności, tłum. Jerzy Łoziński, Scholar, Warszawa.

Mizielińska Joanna, Abramowicz Marta, Stasińska Agata, 2014, Rodziny z wyboru w Polsce. Życie rodzinne osób nieheteroseksualnych, Instytut Psychologii PAN, Warszawa.

Ostrouch-Kamińska Joanna, 2015, Rodzina partnerska jako relacja współzależnych podmiotów, Impuls, Kraków.

Paprzycka Emilia, Mianowska Edyta, 2019, Płeć i związki intymne - strukturalne uwarunkowania trwałości pary intymnej, „Dyskursy Młodych Andragogów”, t. 20, s. 441-455.

Przybył Ilona, 2017, Historie przedślubne. Przemiany obyczajowości i instytucji zaręczyn, Wydawnictwo UAM, Poznań.

Schatzki Theodore, 2012, A Primer on Practices: Theory and Research, w: Joy Higgs, Ronald Barnett, Stephen Billett, Maggie Hutchings, Franziska Trede (red.), Practice-Based Education: Perspectives and Strategies, Sense Publishers, Rotterdam, s. 13-26.

Schmidt Filip, 2015, Para, mieszkanie, matżeństwo. Dynamika związów intymnych na tle przemian historycznych i wspótczesnych dyskusji o procesie indywidualizacji, Fundacja na rzecz Nauki Polskiej-Wydawnictwo UMK, Warszawa-Torun.

Schmidt Filip, Mizielińska Joanna, Stasińska Agata, Olcoń-Kubicka Marta, Żadkowska Magdalena, Jasińska Joanna, Halawa Mateusz, 2018, W stronę socjologii pary: propozycja paradygmatu teoretyczno-badawczego, „Studia Socjologiczne”, nr 3, s. 11-39.

Schmitt David P., Youn Gahyun Brooks, Frye Heather, Johnson Stefanie, Klesman Jenn, Peplinski Catlin, Sampias Jessica, Stoka Christina, 2009, When Will I Feel Love? The Effects of Culture, Personality, and Gender on the Psychological Tendency to Love, „Journal of Research in Personality", t. 43(5), s. 830-846.

Sikorska Małgorzata, 2018, Teorie praktyk jako alternatywa dla badań nad rodzina prowadzonych $w$ Polsce, „Studia Socjologiczne”, nr 2, s. 31-63.

Silverman David, 2007, Interpretacja danych jakościowych. Metody analizy rozmowy, tekstu i interakcji, tłum. Małgorzata Głowacka-Grajper, Joanna Ostrowska, Wydawnictwo Naukowe PWN, Warszawa.

Sprecher Susan, Metts Sandra, 1999, Romantic Beliefs: Their Influence on Relationships and Patterns of Change over Time, „Journal of Social and Personal Relationships”, t. 16, s. 834-851. 
Stasińska Agata, 2018, Socjologia pary. Praktyki intymne w zwiazkach nieheteroseksualnych, Nomos, Kraków.

Sternberg Robert, 1986, A Triangular Theory of Love, „Psychological Review”, t. 93, s. 119-135. Sztompka Piotr, 2008, Życie codzienne - temat najnowszej socjologii, w: Piotr Sztompka, Małgorzata Bogunia-Borowska (red.). Socjologia codzienności, Znak, Kraków.

Szukalski Piotr, 2013, Matżeństwo: początek i koniec, Wydawnictwo UŁ, Łódź.

Taylor Charles, 2002, Etyka autentyczności, tłum. Andrzej Pawelec, Znak, Kraków.

Wojciszke Bogdan, 2009, Psychologia miłości. Intymność, namiętność, zaangażowanie, Gdańskie Wydawnictwo Psychologiczne, Gdańsk.

Żadkowska Magdalena, 2016, Para w praniu: codzienność, partnerstwo, obowiazki domowe, Wydawnictwo UG, Gdańsk.

\title{
SIGNS OF LOVE-PRACTICES OF CREATING INTIMATE RELATIONS
}

\author{
Julita Czernecka \\ (University of Lodz) \\ Abstract
}

The author begins by addressing theories in which love is either the key bond in intimate interpersonal relations (Giddens, Beck, Illouz) or is a set of everyday practices aimed at generating and maintaining a close relationship (Kauffman) and in which love can be understood through certain signs and symbols and other structures of meaning (Danesi). The author's analysis conforms to the concepts of the sociology of everyday life, the sociology of the couple, and the theory of social practices, according to which an intimate relationship is built on the basis of a couple's daily activities, which "produce" that relationship through their repetition. The author analyzes ways of showing love to one another in everyday practices and attempts to embed these gestures and symbols in cultural conditions. The author's reflections are based on a qualitative analysis of empirical research.

key words: love, intimate relationship, erotic love, close relationships, couple, social practices, semiotics of love

słowa kluczowe: miłość, związek intymny, miłość erotyczna, bliskie związki, para, praktyki społeczne, semiotyka miłości 